\title{
Unintended Emission
}

National Cancer Institute

\section{Source}

National Cancer Institute. Unintended Emission. NCI Thesaurus. Code C139490.

Problems due to unintended emission of electromagnetic energy by the device. 